\title{
The editorial history of Conversazione in Sicilia as a case of tense relations between literature and photography
}

\author{
Jan Baetens \& Bart Van Den Bossche (KU Leuven, MDRN)
}

Keywords: Vittorini, Neorealism, Photography, Word and Image

Elio Vittorini's Conversazione in Sicilia, first published in instalments in 1938-1939, then as a book in 1941 , has often been read as an early, yet highly complex and to a certain extent ambivalent example of Neo-Realism. In the novel, two competing aesthetics - that of a realistic and almost documentary narrative and that of a subjective, if not blatantly lyrical testimony - as well as two competing voices that of the contemporary narrator-reporter and that of the immemorial voice of the Sicilian people, embodied in the various anonymous characters the narrator encounters - crave a perhaps impossible balance. In 1953, the novel was reissued by Bompiani with a large number of photographic illustrations, most of which were taken by Luigi Crocenzi in February 1950 during a trip through Sicily with Vittorini. After his return to Milan, Vittorini expressed his irritation about the alleged technical and aesthetic shortcomings of many of Crocenzi's photographs, yet he decided to go on with the illustrated edition, eventually selecting 169 of Crocenzi's photographs together with a limited number of other illustrations. After the publication of the book, Crocenzi openly accused Vittorini of trying to minimize the photographer's role in the project, and even threatened to sue the editor. ${ }^{1}$ The relations between Vittorini and Crocenzi would never be restored. This is surely one of the reasons why, despite the intriguing and impressive character of the iconography (counting for more than half of the printed space in the illustrated edition), the photographs were not reprinted in any of the subsequent editions of Conversazione in Sicilia until 2007, when Bompiani decided to reissue the illustrated edition (it should be noted that in the meantime two other illustrated editions of the book saw the light, both of them with a rather limited circulation). ${ }^{2}$ The aim of this article is not to close-read the very original word and image relationships in Vittorini's work, ${ }^{3}$ but to expand on the meaning and function of the iconography within the broader cultural and intermedial context of Conversazione in Sicilia. We will explicity situate Vittorini's book and its reception within the wider European context of print culture, visual culture and intermediality, and more particularly within the intricate network of relations between literature and photography. It will rapidly become clear that Conversazione in Sicilia cannot be reduced to just another link in the long chain of Sicilian authors,

\footnotetext{
${ }^{1}$ On the editorial history of the illustrated edition, see G. Lupo, Vittorini Politecnico (Milan: FrancoAngeli, 2011), pp; 87-93, and Vittorini's short essay 'La foto strizza l'occhio alla pagina' (1953), now in E. Vittorini, Letteratura arte società. Articoli e interventi 1938-1965, ed. by Raffaella Rodondi (Turin: Einaudi, 2008), pp. 701-706.

${ }^{2}$ See E. Vittorini, Conversazione in Sicilia, ed. by Giorgio Soavi, with photographs by Enzo Ragazzini (Milan: Strenna Olivetti, 1973) and E. Vittorini, Conversazioni in Sicilia, ed. by Sergio Pautasso, with 16 illustrations by Renato Guttuso (Milan: Rizzoli,1986).

${ }^{3}$ For a semiotic analysis of the photographic illustrations in the novel, see B. Van Den Bossche and J. Baetens, 'Conversazioni istoriate: intorno all'edizione illustrata di Conversazione in Sicilia (1953)', Testo. Studi di teoria e storia della letteratura e della critica, 65 (2013), 95-104.
} 
authors-photographers and photographers-authors (from Verga to Sciascia and from Bufalino to Scianna), who relied on photography to offer a more profound and more correct image of a region whose past and present can only be evoked by intermedial (in this case verbo-visual) means. On the contrary, the making and the reception of the 1953 edition of Conversazione in Sicilia, a novel that is both a typical and atypical representative of Neo-Realist literature, is closely tied to a web of broader tensions and tendencies in literary and media culture, linked either to international changes in print culture, either to local factors (and in particular to the development of Neo-Realism in Italian culture).

\section{The Invisible Picture}

Almost every analysis of Conversazione in Sicilia starts with the history of the ways in which the book has been censored, and how an intriguing combination of lyrical enchantment on the one hand and allusions to moral and political anxiety on the other has, from the outset, highly influenced the reception of the work. This entanglement of symbolical overtones and covert political instances (eloquently summarized in the 'astratti furori' mentioned by the narrator in the opening lines of the novel) can rightly be called the hallmark of the work's position in postwar Italian literature. In the critical debate on the novel, however, the longtime absence of the images does not seem to have raised particular questions. The fact that the illustrated edition was almost completely forgotten until 2007 amounts to a complete indifference towards the images (or, even worse, of an indirect case of censorship), the reasons for which are both internal and external.

From an internal point of view, one might argue that Crocenzi's illustrations do not really belong to the work itself, for editorial but also for structural reasons. First off, they were added only afterwards, years after the work was finished, in a period when its position (as well as that of its author) in the postwar Italian literary canon was already firmly established. Moreover, one does not need the images to read the text, for Crocenzi's pictures do not illustrate Vittorini's book in a literal way, while the text, for obvious reasons, never relies directly on its iconography. Therefore the images accompany the text as a parallel but distinct narrative parcours, and could therefore be seen as unnecessary or even superfluous.

From an external and perhaps more important perspective, the illustrated version of Conversazione in Sicilia may be connected to the deeply-rooted suspicion towards the image, more specifically the photographic image, in the European literary tradition. Given the fact that Vittorini has repeatedly claimed the 'authorship' of the images, reducing Luigi Crocenzi's role to that of a mere 'technician', and given Vittorini's strong interest in the interaction between photography and literature (see especially the use of photographic illustrations in the anthology Americana) ${ }^{5}$ this is the more intriguing question. In order to fully grasp this aspect of Conversazione in Sicilia, one should recognize the long-standing tradition of anti-illustrative stances, taken up by high-art authors struggling to defend 'serious', if not elitist literature, against the rapid spread of so-called industrial literature (a term coined by the French critic Sainte-Beuve in the years that followed the early $19^{\text {th }}$ century technological revolution in the printing business and the subsequent explosion of popular literature ). ${ }^{6}$ Vittorini considered mass media (in particular radio, television and newspapers) at best as mere instruments of dissemination, at worst as vehicles of an ongoing industrialization of mass culture that

\footnotetext{
${ }^{4}$ See Vittorini, Letteratura arte società, pp. 697-8 and pp. 701-706.

${ }^{5}$ E. Vittorini, Americana (Milan: Bompiani, 2012 [1941]).

${ }^{6}$ See J. Baetens, 'Popular Fiction', in The English Literature Companion, ed. By J. Wolfreys (London: Palgrave, 2011), pp. 244-249.
} 
challenged and threatened the creative and innovative functions of high-brow humanist literature and culture (see for instance the 'Premessa' to the first issue of II Menabò). ${ }^{7}$

With regard to visualization, the case of Gustave Flaubert and that, much more ambivalent already, of Henry James, ${ }^{8}$ have become famous, and still inspire many authors claiming that any visualization of the literary text narrows and hence frustrates the reader's imagination instead of stretching it (similar cases are still made against cinematographic adaptations, but that is a slightly different issue, which we shall not tackle here). More specifically, the argument goes beyond the difference between the text's imaginary polyphony and its reduction to one single solution by the image. In the case of the photographic image, two other elements deteriorated, in the eyes of quite some high-art authors, the text's richness and purity. First of all the fact that pictures are indexical documents, whose reproduction of reality is incompatible with the fictional status of the literary text. Second, the fact that pictures are machine-made images, whose mechanic character cannot compete with the subjective and creative qualities of literary writing and art tout court. ${ }^{9}$

It should not come as a surprise, then, that the most direct attempt to merge literature and photography in twentieth century writing, André Breton's Nadja, ${ }^{10}$ reflects, at least in theory, a completely different stance towards writing and literature. Breton himself has written extensively on the use of photographs in his memoir, and the place of the specific images of the book in the new approach of literature that he was defending. Photographs did not only aim at taking the place of the boring and useless visual descriptions (a statement already made by the author in the first Surrealist manifesto of 1924), ${ }^{11}$ they were also crucial devices in the battle against institutionalized literature, which Breton discarded as aesthetic, fictional, and therefore irrelevant, and which he proposed to replace by writings conceived of as scientific documents, regardless of the moral and aesthetic standards regulating the work of the writer. Images, more specifically anonymous, technically imperfect, found-object photographic images (badly printed postcards bought on the flea market for instance) were perfect carriers of the revolutionary form of anti-literature that the first Surrealism claimed to represent. ${ }^{12}$

Despite Breton's efforts to promote this new form of intermediality, also exemplified by Les vases communicants (Communicating Vessels) and L'amour fou (Mad Love), ${ }^{13}$ the Nadja formula did not prove very successful. The literary system - authors, readers, publishers, critics, historians - remained vastly suspicious of the combination of text and pictures in literary works, at least in the field of fictional and autobiographical prose (the situation of poetry was somewhat different, as shown by Jane Rabb and Michael North, ${ }^{14}$ among others). Nadja can be said to be the work that had initiated

\footnotetext{
${ }^{7}$,Now in Vittorini, Letteratura arte società, pp. 866-868

${ }^{8}$ See A. Tucker, The Illustration of the Master. Henry James and the Magazine Revolution (Stanford: Stanford University Press, 2010).

${ }^{9}$ La Photographie en France: Textes \& controverses, une anthologie, 1816-1871, ed. by A. Rouillé (Paris: Macula, 1998).

${ }^{10}$ A. Breton, Nadja, tr. Richard Howard (London: Grove Press, 1994). (Original edition: Nadja, 1928)

${ }^{11}$ A. Breton, Manifestoes of Surrealism, tr. Richard Seaver (Ann Arbor: Michigan University Press, 1969) (Original edition: Les manifestes du surréalisme, 1955).

${ }^{12}$ See M. Poivert, L'image au service de la révolution (Cherbourg: Point du Jour, 2006).

${ }^{13}$ A. Breton, Communicating Vessels, tr. Mary Ann Caws and Geoffrey T. Harris (Lincoln: University of Nebraska Press, 1997) (Original edition: Les vases communicants, 1932); A. Breton Mad Love, tr. Mary Ann Caws (New York: Bison Books, 1988). (Original edition: L'amour fou, 1937).

${ }^{14} \mathrm{~J}$. Rabb, Literature \& Photography: Interactions 1840-1990 : A Critical Anthology (Albuquerque: University of New Mexico Press, 1995), M. North, Camera Works. Photography and the Twentieth-Century Word (New York: Oxford University Press, 2007).
} 
the merger of text and photography in high-art writing, ${ }^{15}$ but although widely read and never published without its images (much like Georges Rodenbach's 1892 symbolist novel Bruges-la-Morte, Breton's book did not succeed in launching a new literary movement. It is only much later, thanks to the converging effects of the visual turn in culture, the worldwide triumph of W.G. Sebald's novels (close to Nadja yet distant from Breton), the technological revolution of word processing and printing techniques that abolished the frontier between text and image, and, last but not least, the rapid integration of the photographic medium in the very heart of the contemporary art system, that photography would establish a more prominent position in literature - even in fiction, the fortress that until recently has resisted most vehemently the invasion of the image.

Within this broader framework, the status of Conversazione in Sicilia is a real paradox: in the images in the 1953 edition are clearly symptomatic of the author's documentary ambitions, as they emphasize the strong link between the narrative act (or, for that matter, the readerly act) and the Sicilian landscape and its inhabitants. ${ }^{16}$ That Crocenzi's photographs appear alongside seven pictures taken by Giacomo Pozzi Bellini in 1938 and a set of twelve postcards seems to point in the direction of the construction of a truly visual narrative parcours with materials of different kinds (and this attention to visual culture and visual narrative in particular is, as is well known, a distinctive feature of Vittorini's literary and critical work). However, as has already been emphasized, the illustrated edition would not be reprinted until 2007 and virtually disappears from literary memory. On the immediate institutional and editorial level Vittorini's decision not to reprint the book is due to the fundamental disagreements between the author and Luigi Crocenzi that occurred during and after the publication of the illustrated edition, yet, on a more general level, the absence of any reference to the images from all subsequent editions suggests that Vittorini's documentary aspirations do not imply any refusal of the classic literary framework that the author was looking for.

But there is more to Vittorini's illustrated edition of the Conversazione, that can best be grasped by looking at the specific context of the novel, and in particular at the striking position of visual culture of the 1950s in Italy.

\section{Undesired Illustrations}

As already argued, a writer's attitude towards pictures does not depend solely on his or her personal vision regarding the elaboration of a specific literary work. What authors think and perform in their work, cannot be separated from the larger set of perceptions and convictions that structure the literary field, its internal organization and the changes it goes through. In the case of the relationship between photography and literature, three major aspects must here be taken into account.

First of all, it should be noted that the absence of photographic images in texts does not necessarily imply that photography as a medium is absent from the literary production itself. As argued by Philippe Ortel in a seminal book on the mutual shaping of literature and photography, ${ }^{17}$ the invention and dissemination of photography (differently patented in France and Britain in 1839) has been the starting point of what he calls an 'invisible' revolution in the literary mediascape. So immediate and so universal was the spread of photography, that culture as a whole, including the field of literature,

\footnotetext{
${ }^{15}$ See P. Edwards, Soleil noir. Photographie et littérature des origines au surréalisme (Rennes: Presses Universitaires de Rennes, 2008); P. Ortel, La littérature à l'ère de la photographie. Enquête sur une révolution invisible (Nîmes: Jacqueline Chambon, 2002), J. Thélot, Les inventions littéraires de la photographie (Paris: Presses Universitaires de France, 2003).

${ }^{16}$ On this function of "spatial anchoring" (ancoraggio spaziale), see Van den Bossche and Baetens, 'Conversazioni istoriate', 99-100.

${ }^{17}$ Ortel, La littérature à l'ère de la photographie.
} 
was subjected to its aftereffects and forced to adapt to a totally new situation. ${ }^{18}$ As far as literature was concerned, the photographic revolution did not take the form of a rapid hybridization of the literary text: photographic illustrations remained rare, not only because they were expensive to add to printed books (printing texts and photographic images simultaneously became possible only from the 1880 s onwards), but also because photographs continued to be seen as second-rate illustrations (in comparison with engravings, they were considered less narrative and less rhetorical). ${ }^{19}$ Instead, photography penetrated the literary domain in more surreptitious though no less significant ways. Ortel claims that during the nineteenth century (and for him this process still continues), literature became photographic, even if no pictures were included or mentioned in the text. What happens goes much deeper than the sole issue of photographic illustrations: first, the very process of writing is conceptualized in photographic terms (the writer records in the dark room of his mind and then develops the images by writing them down on paper); second, the selection of what will be written or told is now framed in photographical terms (it is the photographically reproducible that determines what can or cannot be said); third, the symbolic reading of what is being written or said is done according to photographic parameters (we read a text the same way as we look at photographs).

In spite of this strong pressure towards a major input of photography, the literary field did not react enthusiastically to the insertion of pictures, except in popular literature, where photographic illustrations rapidly replaced drawings and engravings. Given the abyss that for many decades separated popular and elite literature, the very success of photographically illustrated books in the popular segments of book production undoubtedly raised the general fear of images in 'serious' literary circles. In the interwar period, there were two main types of popular books. First of all, there was a very flourishing market for so-called 'photographic novels', ${ }^{20}$ i.e. novels by best-selling and easy-reading authors who did not have any aesthetic or status-related problems in completing their fiction with photographic material (in France a good example was Pierre Loti, the author of highly successful colonial novels; an example of an Italian colonial novel illustrated with photographs is Giuseppe Fanciulli's Tra le lance dei Galla (1936)). Despised by progressive and more demanding authors, these books certainly reinforced the high-brow reluctance towards newer forms of illustration. Besides these photographic novels, on a sociologically much lower level, there was the almost industrial production of cheap novelizations, i.e. of novels based on films.$^{21}$ Often very unsophisticated in form as well as in content (most novelizations of this type were hasty rewritings of cheaply printed film scripts), these frequently contained rather elaborate series of pictures (set photographs rather than film stills). Among the most well-known Italian examples are the book series Le Grandi Films and Romanzo-Film, both published by the Milanese publishing house 'Gloriosa'Vitagliano in the second half of the twenties. ${ }^{22}$ The bad reputation of these works, often written by professional authors who refused to publish them under their own name, did the perception of photographic images in literary texts no favours.

Conversazione in Sicilia is clearly marked by this profoundly problematic tension between the pressure exerted by photographic culture and literature's desire to legitimize itself. The emphasis put on voice and speech in the title ('conversazione') as well as in the book's countless and highly stylized quotations of Sicilians speaking (as if we were transported to the dialogues between protagonists,

\footnotetext{
${ }^{18}$ See also R. Ceserani, L'occhio della medusa. Fotografia e letteratura (Torino: Bollati Boringhieri, 2011).

${ }^{19}$ See M. A. Sandweiss, Print the Legend (New Haven, CT: Yale University Press, 2002).

${ }^{20}$ See A. Reverseau, Le rôle de la photographie dans l'esthétique moderniste: changer le regard du poète (unpublished PhD 2011).

${ }^{21}$ J. Baetens, Pour le roman-photo (Brussels: Les Impressions Nouvelles, 2010).

${ }^{22}$ See R. De Berti, “"King Vidor comes to Italy”: dai film alle trasposizioni in romanzo di The Big Parade e The Crowd', in II racconto del film. Narrating the Film. La novellizzazione dal catalogo al trailer, ed. by Alice Autelitano and Valentina Re (Udine : Università degli Studi di Udine DAMS/Gorizia, 2006), pp. 123-138.
} 
assembled as choruses in an ancient drama), the weight given to the narrator and his skillful manipulation of narrative time (in contrast to the supposed fixity of the photographic picture), and the blatant refusal to stick to the traditional aesthetics of illustration (which always carries the danger of dwarfing the text, helpless in comparison with images that may be worth a thousand words): all these features display a fierce attempt to foreground the specific, i.e. verbal and therefore non-visual, aspects of writing. At the same time, the very insistence on all these aspects can also be interpreted as a struggle with the implicit power of what has been kept in the margins of the text and has literally remained out of sight.

Vittorini's decision to add photographic illustrations to an already existing novel cannot be explained as a mere attempt to shift the book's readership and target a broader and less educated audience. On the contrary, there were many other, and often very good reasons for the shift from a traditional, non-illustrated version, to a new, photographically illustrated one, and most, if not all, of these reasons have to do with the configuration of the literary field at the times.

\section{The Literary Semiosphere}

Semiotically speaking, dominant literary models are structured according to a dynamically changing cartography that distinguishes three domains: culture (divided into a center, where the canon of a certain period is situated, and various kinds of more or less peripheral margins), anti-culture (which represents the types and models opposed by a given culture), non-culture (a reservoir of structures and possibilities that do not play an active role in the tension between culture and anti-culture) ${ }^{23}$ Conversazione in Sicilia is a book that helps exemplify the often rapid changes in such a system. In its initial resistance to the image through specific writing strategies, it embraces the traditional idea(I) of literature as an artful recomposing of the social voice. From a semiotic perspective, Vittorini's literary strategy can be read as a clear canonizing gesture, aimed at stressing the abyss between Conversazione in Sicilia and other, 'lower' forms of publication, marked by the anti-cultural fascination with the image as represented by the dominating media of mass culture (popular cinema on the one hand, illustrated newspapers and magazines on the other hand). Within the same framework, the choice for a photographically illustrated edition of the novel is then less a surrender to the margins of culture or to its anti-cultural opposite than a sign of the growing awareness that it is neither possible nor desirable to maintain the divide between traditional literary-artistic culture and newer forms of non-culture or anti-culture. Once again, such a swing is not the result of an individual decision taken by an individual author. It reveals the way in which a specific agent, in this case Vittorini, tries to reposition himself in a changed and ceaselessly changing context in which the overwhelming presence of photography as a cultural practice, through the various uses that it enables or reinforces, puts fierce pressure on the necessity to respond to the 'invisible' revolution triggered by the photographic paradigm. In this respect, Vittorini's well-documented fascination with various kinds of visual culture throughout his writing career makes him a very interesting example of a writer trying to negotiate his identity as a literary agent in a rapidly changing media culture.

In the years after the first edition of Conversazione in Sicilia (1941), modern visual culture continued to penetrate the literary domain from all sides, in particular in a number of subgenres related to Vittorini's novel. The latter, in fact, goes back and forth between travel literature, autobiography, journalism, realist fiction or, if one prefers, between old and new forms of publishing as well as between classic fiction and experimental types of literary documents and personal testimony ${ }^{24}$

\footnotetext{
${ }^{23}$ Y. Lotman, Universe of the Mind, tr. Ann Shukman (London: Tauris. 1990).

${ }^{24}$ On the document in literature, see Littérature et document autour de 1930. Hétérogénéité et hybridation générique, ed. by Sarah Bonciarelli, Anne Reverseau and Carmen Van den Bergh, special issue of La Licorne, 113 (april 2014).
} 
An example of a novel strongly imbued with patterns and schemes from travel literature, Conversazione in Sicilia can obviously be related to the rapid spread of photographic material in this sort of writing in the 1930s. Of all institutionalized literary genres, it was undoubtedly travel literature that was the first to welcome visual contributions. Already present in non-literary texts such as travel guides and touristic brochures, photographs quickly entered the literary field through a certain number of subgenres that became very popular in the pre-war decade (and that were continued in the post-war decade).

First came the photographic representation of the major metropoles (Paris, Berlin, London, New York), often prefaced by well-known writers having a certain affinity with modern life and city culture. The best known example of such a book is Brassaï's 1933 Paris de nuit (Paris by Night), with a preface by Paul Morand, then considered the typical representative of the Jazz Age in literature. ${ }^{25}$ Published as a special issue of the highly prestigious journal Arts et métiers graphiques (Paris-based, but actually very European in its editorial policy), Paris by Night bridged a double gap: that between photography and writing, but also that between documentary writing and literature. Although text and image remain separated, as demonstrated by the fact that Morand is never credited as its coauthor (officially he is mentioned as 'contributor'), Paris by Night has played a key role in the progressive merger of photography and literature. In the post-war years, similar books continued to appear, but the focus shifted from the representation of the city to that of the country. Given the link between war and nationalism, there followed a boom of country photography, often in a comparative fashion (Cartier-Bresson's 1955 book Les européens (Europeans) being a good example of this tendency).$^{26}$ In many cases, however, the national dimension was treated in regional, regionalist or even local terms - in some cases to avoid to confusion between the national and the nationalistic -, as will become very clear in Italian Neo-Realism (two of the best-known examples are Un paese by Paul Strand and Cesare Zavattini, published in 1955, or Milano, Italia by Mario Carrieri, 1959).

The second genre that exerted a similar influence on the encounter between literature and photography was the photographic essay, launched by the new picture-oriented magazines of the 20 s and the 30s such as Vu, in France, Life and Picture Post in the Anglophone world, or Tempo and (to a lesser extent) Omnibus, in Italy. For the photo-essay, Life, launched in 1936, has played a crucial role, but the swift public success of the formula (introduced in Italy in 1939 by Tempo) ${ }^{27}$ does not of course suffice to explain its contribution to the changes in the literary field. After all, in the typical photo-essays as introduced by Life and taken up by Tempo, writing was inferior to imagery and did not claim literary value, while its use of photography also had strongly anti-artistic undertones. Patrizia Vettel-Becker e.g. argues that documentary photography in mass media publications constituted a gendered critique of the 'feminized' art scene that other forms of photography were trying to enter. ${ }^{28}$ If the model of the photo-essay became of some importance to the literary field, it was also because of the simultaneous presence and influence of the more high-brow photographic city portraits and their integration in the literary network of modern literature. In that regard, Conversazione in Sicilia is a much better example of the fusion of text and photography than a book such as Let Us Praise Now Famous Men by James Agee and Walker Evans (1941, but actually composed in 1936), which is both a reflection and a violent critique of the form and ideology of the

\footnotetext{
${ }^{25}$ Brassaï. Paris by Night. (New York: Bulfinch Press, 2001) (Original edition: Paris de nuit, 1933).

${ }^{26}$ H. Cartier Bresson, Europeans (London/New York: Thames and Hudson, 1999) (Original edition: Les européens, 1955).

${ }^{27}$ See A. Russo, Storia culturale della fotografia italiana. Dal Neorealismo al Postmoderno (Turin: Einaudi, 2011), p. 18, p. 83.

${ }^{28}$ P. Vettel-Becker, Shooting from the Hip: Photography, Masculinity, and Postwar America (Minneapolis: University of Minnesota Press. 2005).
} 
photo-essay as well as of tourist and travel literature. ${ }^{29}$ What Vittorini is doing illustrates more conspicuously the visual language of the photo-essay, while upgrading it to the dignity of literature by balancing text and image. Vittorini's text is not a preface to Crocenzi's images (as is Morand's text in Paris by Night), and neither is it an expanded version of the pictures' captions, as in the illustrated press. Yet it still breaks down the frontiers between photography and writing, as maintained by Agee and Evans.

For yet another way to measure the innovative qualities of Conversazione in Sicilia let us now take a look at II Politecnico, the political magazine edited by Vittorini between 1945 and 1947 (in this context, too, one should refer to the anthology Americana, published in 1942)..$^{30}$ This magazine, a leftist answer to the vogue of the illustrated news magazines that were flooding Italy after the war (with Oggi and L'Europeo as the most notorious examples), combined word and image either along the lines of the classic illustrative model (with pictures meant to highlight certain aspects of the text, not vice versa, as was the case in the typical photo-essay style of capitalist publications such as Life) or by adopting a more modernist model, giving full priority to the image at the expense of the text. In II Politecnico, the pictures were supposed to speak for themselves, for instance through visual montage techniques. This was of course a model inspired by certain forms of Soviet photojournalism, also alluded to by the 'constructivist' page lay-out and typography of the magazine. ${ }^{31}$ Some issues of II Politecnico contain images or reportages by Crocenzi, ${ }^{32}$ and the differences with Conversazione in Sicilia are striking: in certain cases they simply illustrate the text; in other cases, they are presented as a sequence of film stills, with hardly any text or commentary (see for instance 'Andiamo in processione', a so-called 'photographic tale' on a religious procession in a village in II Politecnico 35, pp. 54-59). In this regard, Conversazione in Sicilia is more than just a continuation of the project of II Politecnico: it should be read as a critique of the verbo-visual rhetoric of the magazine, which despite its modernist typography did not always rely on the constructivist montage principles that one would have expected in a publication exemplifying the 'red sign'. ${ }^{33}$ Much more than II Politecnico, Conversazione in Sicilia therefore endeavours to remediate some major innovations of the 1930s - the progressive merger of photography and text as equal partners, not only in quantitative but also in qualitative terms - while avoiding the ideological pitfalls of both mass media (which reduced the function of the word and therefore prepared the emergence of the spectacle culture to be theorized by Debord) and high modernism (which tried to integrate pictures in the realm of canonical literature, yet without accepting a full merger of the media of photography and writing).

Why then was this attempt considered unsatisfactory by Vittorini? Why did he not continue the experiment tried out in Conversazione in Sicilia? Specific biographical and editorial circumstances, such as the above-mentioned conflict between Vittorini and Crocenzi, the very limited and predominantly negative attention paid to the book by critics, the unwillingness of Bompiani to continue a line of books with an uncertain commercial future, all played a role. But in the long run, and within the broader context of changing relations between media, other structural factors may have been much more decisive. From this point of view, the position of the book in the larger literary field, with photographically illustrated editions rapidly gaining ground in the post-war years, was of great importance. One of the most salient aspects of post-war publishing (in France, for instance, but also in other countries) was the tremendous success of book clubs, i.e. of associations offering to their paid-up members fairly cheap access to certain categories of books, mainly new editions of

\footnotetext{
${ }^{29}$ J. Agee and W. Evans, Let Us Praise Now Famous Men (New York: Houghton Mifflin, 2001) (Original edition 1941).

${ }^{30}$ See II Politecnico, ristampa anastatica dal n.1 (29 sett. 1945) al n. 39 (dic. 1947) (Milan: Einaudi, 1989).

${ }^{31}$ See A. Petrucci, La scrittura. Ideologia e rappresentazione (Turin: Einaudi, 1986), pp. 144-147.

${ }^{32}$ See Conversazione illustrata, ed. by Maria Rizzarelli (Palermo: Bonanno, 2007), pp. 75-102.

${ }^{33}$ Petrucci, La scrittura, p. 143.
} 
classic books and recent bestsellers. In order to seduce the general public and to foster membership, these book clubs took special care of the visual presentation of their publications. They did so either by hiring young and experimental typographers who accepted to practice what the famous French typographer Massin used to call 'elitism for all' and to devote the best of their forces to cheap pocket book editions, or by including photographic illustrations in the works that they were reissuing. Given the direct dialogue between Italian and French cultural life in that period (in cultural life at large and especially in leftist circles), it should be assumed that Vittorini was perfectly aware of what was happening in the French publication market in which the French Communist Party was an important player. The word and image interaction in Conversazione in Sicilia is strikingly similar to this model and in particular to its agenda of democratization of picture books; yet from an aesthetic point of view the illustrated edition of Vittorini's novel goes much further than what book clubs were proposing to their popular readership in the post-war period. In that sense, the collaboration between Vittorini and Crocenzi radicalizes the aesthetic and political message of the photographically illustrated book of that period, and could have represented a fruitful model for new, contemporary as well as democratic forms of publishing that managed to respect the artistic integrity of both writers and photographers. Nevertheless, this apparently very promising road was never taken. In order to understand this decision, we have to turn finally to where the reading of Conversazione in Sicilia normally starts: Neo-Realism.

\section{Neo-Realism against the Image}

As has been pointed out by various scholars, Neo-Realism is a profoundly ambivalent movement, taking place in a no less multifaceted historical context. ${ }^{34}$ Its attempt to break with a Fascist culture that in its modernist stances had incorporated many aspects of the Futurist revolution, its combination of innovative and restorative tendencies at a moment of national rebuilding, and its impossibility to simply recover the techniques and ideology of previous forms of Realism, make NeoRealism a welcome home to impure forms of art, politics, and social action. Moreover, Neo-Realism is also deeply determined by its relationship to visual culture, more specifically to representations of the Italian landscape, which had suffered greatly throughout the Fascist era and the Second World War, and would continue do to so during the years of Italy's economic miracle. ${ }^{35}$ As an example, it may suffice here to remember Rossellini's portraiture of the Pompeii and other ruins in a film like Viaggio in Italia (released the same year as Vittorini's book, 1953). Here again, the illustrated edition of Conversazione in Sicilia can be called 'typically' Neo-Realist, despite the discrepancy in writing style between Vittorini's book and the more explicitly social and political stances of many post-war NeoRealist novels. In the case of Crocenzi's images, that discrepancy is much less noticeable, due to the large number of portraits and close-ups of interiors and artefacts. The photographs do not remove this distance completely, however, because of the emphasis on the quasi-mythological, changeless sides of the Sicilian landscape and the inclusion of snapshots and postcards of monuments and works of art from various historical periods. In Vittorini's novel, images of poverty and deprived living conditions are constantly combined with references to cultural artefacts (such as Sicilian puppets or pupi) or with highly symbolical images (such as the series of staircases in the central part of the edition, pp. 107-146). Due to this constant interweaving of realist scenes and stylized representations, even the pictures of village life evoke the Sicilian environment in a less straightforward way than Luchino Visconti's La terra trema (1948), to take one of the examples that can be easily associated with Conversazione in Sicilia.

\footnotetext{
${ }^{34}$ N. Steimatsky, Italian Locations. Reinhabiting the Past in Postwar Cinema (Minneapolis: University of Minnesota Press, 2008); G. Nisini, Il neorealismo italiano. Scritture, immagini, società (Roma: Giulio Perrone Editore, 2012).

${ }^{35}$ Steimatsky, Italian Locations.
} 
The question remains why later editions of Vittorini's book wiped out an aspect of its visual and cultural heritage that appealed so much to the image of Italy as constructed by Neo-Realist imagery. The reasons were probably manifold: biographical and aesthetic, as already hinted at, but also historical and political. Neo-Realism, indeed, was changing in the years surrounding the publication of Conversazione in Sicilia. For one, Neo-Realist photography as it had been taken up by post-war mass culture, became increasingly dominated by highly conventional associations between recognizable social issues, a preference for the anecdotical and the picturesque, and a straightforward emotional interpretation of the scene. Neo-Realist film witnessed an important shift in the early fifties as well. With the reopening of Cinecittà in 1947, and the implementation of NeoRealist filmmaking in the traditional studio system, Neo-Realism had lost some of its sting, and its tone became sunnier. Yet the emergence of the Italian comedy, often called 'pink Neo-Realism' in these first years, was not the only mutation of the movement. Looking back at the example of Viaggio in Italia, a film whose importance for the conceptualization of New Wave cinema can hardly be overstated, another shift becomes apparent. According to the French critic Jacques Rivette, spokesman of the Cahiers du cinéma and the rising auteur's theory, Viaggio in Italia was the work that really enabled a new start in European film making ${ }^{36}$ Yet the new approach, strongly influenced by the Christian-existentialist ideology of personalism, was received by leftist critics as a betrayal of cinema's social responsibilities. As summarized by John Hess:

The individual, not the universe or even the individual in society, became the auteur critics' central concern. [...] These lonely moral and spiritual struggles are at the center of the films considered important by the auteur critics. An auteur, therefore, is the director who most convincingly and most directly presents the fullness of this struggle by the most visual means possible: the human gestures and movements on the screen, the composition of the visual images-in short, the mise en scene. [...] This view of people is the essence of auteur criticism; the aesthetic construct erected above this basic world view is an elaborate justification and rationalization of this very limited view of what film can and should do. ${ }^{37}$

Although Hess denounces the French production as much as the Italian, ${ }^{38}$ it is clear that the shifts in Rossellini's work, by far the most important and influential Italian director of these years, do not fall outside this kind of criticism, and it is not implausible to suppose that Vittorini's unease with the visual counterpart of Conversazione in Sicilia had something to do with the gradual transformation of the Italian landscape, the Italian territory, and the Italian visual setting into a metaphor of the character's attitude toward life and the others. Paradoxical as this may appear in hindsight, the exclusion of the visual dimension of Conversazione in Sicilia can be understood as an attempt to save the original Neo-Realist orientation of the work and to keep it away from the growing psychologization of neo-realist themes, patterns and genres. For Vittorini, as for some of his NeoRealist fellow travellers such as Italo Calvino, space should remain an explicative and foundational part of the program of social change, instead of being downsized to the external representation of an individual mind. In this regard, one may interpret Vittorini's decision, in 1957, to reject Lampedusa's II Gattopardo for the 'Gettoni' series and to redirect the novel towards Mondadori ${ }^{39}$ as the structural flipside of his decision to withdraw Crocenzi's images from the subsequent editions of Conversazione in Sicilia: in both cases contingent circumstances may have played an important role, yet from a

\footnotetext{
${ }^{36}$ For a discussion of the reception of Rossellini's film in cinephile auteur milieus, see $A$. de Baecque, $L a$ cinéphilie. Invention d'un regard, histoire d'une culture. 1944-1968 (Paris : Fayard, 2003).

${ }^{37} \mathrm{~J}$. Hess, 'La politique des auteurs (part one) World view as aesthetics'. Jump Cut, 1 (1974), 19-22. Available online: http://elise.arts.kuleuven.be/moodle/file.php?file=\%2F13\%2FLa politique des auteurs Hess.pdf (accessed October 4th 2014).

${ }^{38}$ On Italy, see E. Morreale, Così piangevano. Il cinema melò degli anni Cinquanta (Roma: Donzelli, 2011).

${ }^{39}$ See G.C. Ferretti. La lunga corsa del Gattopardo (Torino: Aragno, 2008), R. Crovi, Il lungo viaggio di Vittorini. Una biografia critica (Venezia: Marsilio, 1998), pp. 384-388.
} 
broader perspective they are tantamount to a strong confidence in the literary programme embodied in Conversazione in Sicilia as well as in the editorial line of the 'Gettoni' series.

But there is more, and again the internal changes and updates of Neo-Realism are crucial. Successful films were not the only link between Neo-Realism and the new or restored mass media culture: as conspicuous was the rapid integration of film production in the then exceptionally popular medium of the photonovel or fotoromanzo, an Italian invention. ${ }^{40}$ The success of the genre eventually enabled the complete assimilation of the film-novel into the format of the photonovel: film-novels published in this format were called cineromanzi ${ }^{41}$ This integration, however, was not without danger for the integrity of the original work: films that were reissued as cineromanzi largely adopted the aesthetic as well as the narrative and the ideological format of the fotoromanzi, which were basically melodramas, even if the actual production was more diverse than has been said. ${ }^{42}$ As pointed out in various essays gathered by Morreale films that became cineromanzi were not just films reissued in magazine format, but works whose basic structures were adapted to the wellestablished and formulaic photonovel mould which was often at odds with the singularities of the films that were adapted. This meant for instance the acceptation of a conventional page grid of six identical images, arranged in three strips of two images, i.e. a page lay-out that was much more rigid than that of the average photonovel. It also implied the reduction of the story to an elementary script that could easily be serialized in a limited number of instalments (most cineromanzi have no more than 48 pages, and many of them are shorter). Moreover, it signified the rewriting of the story in dialogue form, the images being nothing more than a visual help to the unfolding of the words whose style was invariably that of nineteenth century popular literature. Finally, it also resulted in the generalization of the melodrama format that structured the whole universe of the photonovel production. This astonishing remediation of film production as cineromanzi may seem logical or acceptable for many mainstream films that flooded Italy in these years, but it is important to stress that Neo-Realist film production did not escape this brutal reconversion. Flipping through the catalogue of the cineromanzi exhibition organized by the Turin branch of the Italian Film Institute, one is immediately struck by the overwhelming homogeneity of a corpus that embraced the totality of what was shown in Italian theatres, from the American blockbuster to the 'French Quality' movie and from the local comedy to the politically involved Neo-Realist movie. Translated in the language of the photonovel, all these films became identical. It is not difficult to imagine that this cultural and ideological streamlining raised serious problems to leftist filmmakers, scriptwriters, critics, and moviegoers (and to a certain extent to the fotoromanzo readers as well, who tended to discard the cineromanzi as snobbish). ${ }^{43}$ Here as well, the fact that between the 'exception' of the 1953 edition and Vittorini's death in 1966 all editions of Conversazione in Sicilia will be exclusively textual can be seen as a highly symbolic gesture of resisting the upcoming spectacularization of culture and the blind assimilation of all critical material by the communication and entertainment industry.

While in the case of pink comedies such an integration is in no way problematic, the psychologicalexistentialist turn of Neo-Realism becoming auteur cinema will try to have its cake and eat it by launching new forms of film-novels (often in overt competition with other types of remediation such as novelizations and the already mentioned cineromanzi). ${ }^{44}$ Apparently, Vittorini took a more radical stance: he refused to adapt Conversazione in Sicilia to the new commercial standards of the day, which he must have considered a serious threat to the political subtext of his success novel, but he

\footnotetext{
${ }^{40}$ A. Bravo, Il fotoromanzo (Bologna: Il Mulino, 2003), J. Baetens, Pour le roman-photo (Brussels: Les Impressions Nouvelles, 2010).

${ }^{41}$ Lo schermo di carta. Storia e storie dei cineromanzi, ed. by Emiliano Morreale (Milan: Il Castoro, 2007); Morreale, Così piangevano.

42 J. Baetens, 'The Photonovel: Stereotype as Surprise', History of Photography, 37 (2013), 2, 137-152.

${ }^{43}$ See Morreale, Così piangevano, pp. 293-298.

${ }^{44}$ See II racconto del film / Narrating the Film.
} 
also seems to have abandoned the experimental search for new ways of combining literary fiction and images, preferring an almost iconoclastic withdrawal to the realm of the text. Seen in this way, it can hardly be a coincidence that the other illustrated editions of Conversazione in Sicilia were published only after Vittorini's death, the first in 1973 (with photographs by Enzo Ragazzini) and the second in 1986 (with illustrations by Renato Guttuso made in the early 1940s. As material objects, however, texts are never limited to a single appearance or a single meaning. The editorial life of Conversazione in Sicilia will therefore not end with Vittorini's decision, and the 2007 republication of its illustrated, and subsequently self-censored version, will be one of the opportunities to reread afresh certain aspects of this key document of post-war Italian culture and literature. 